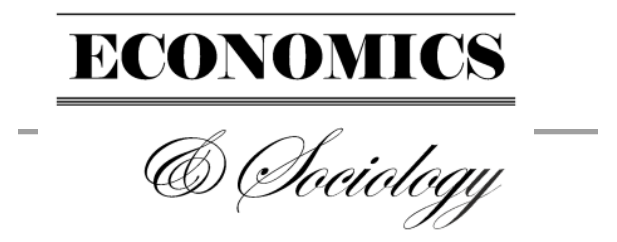

Tomasz Sikora,

SGH Warsaw School of

Economics,

Warsaw, Poland,

E-mail: tsikora@sgh.waw.pl

Ewa Baranowska-Prokop,

SGH Warsaw School of

Economics,

Warsaw, Poland,

E-mail:ebarano@sgh.waw.pl

Received: July, 2018

1st Revision: August, 2018

Accepted: October, 2018

DOI: $10.14254 / 2071-$

789X.2018/11-4/7
JEL Classification: L10, M10, L31

\section{EXPLAINING SUCCESS PERCEPTION OF POLISH INTERNATIONAL NEW VENTURES: FOUR PERSPECTIVES}

ABSTRACT. The main objective of this paper is to evaluate the impact of the following four groups of factors on success perception by managers of Polish small- and medium-sized international new ventures (SMEs INVs): 1) competitive strategy expressed by international orientation of top management and applied marketingmix tools, 2) competitive strategy analyzed within M.E. Porter's framework, 3) sector-specific determinants (industrial branches), and 4) main export markets. Two measures of success perception are considered: subjective evaluation of firm's financial situation and assessment of firm's success as compared to competitors. The methods of data analyses are correlations and multiple linear regression (SPSS software). The analysis is conducted separately for smallsized companies and for medium-sized firms. The hypotheses concerning the roles of international orientation, marketing-mix tools, industrial branches, and main export markets in explaining success have been fully or partially confirmed. The factors that are most positively related to the perception of success across both groups of firms and two measures of success perceptions are high-quality products, good product development strategy and capability to create unique products, i.e. differentiation strategy. The obtained results imply that the most fundamental factor of success is a good product policy within the framework of a differentiation strategy. The second objective of this paper is to provide a comparison between small and medium-sized enterprises, analyzing whether there is a reason to consider SMEs as a uniform category, or whether the factors explaining success are different depending on firms' size.

Keywords: International New Ventures, Born Globals, Success Perception, Competitive Strategy, Marketing-mix, Performance. 


\section{Introduction and literature review}

The globalization processes are decisive factors in facilitating fast internationalization of firms, especially those from the SME sector. Over the last thirty years, a number of internationalization models and theories has been created (Cieślik \& Michałek, 2018; Androniceanu \& Popescu, 2017). Some relatively new approaches have given rise to a phenomenon often labeled as "Born Globals". This term was first used by (Rennie, 1993), and it describes companies satisfying the following criteria:

SMEs deriving at least 25 percent of their revenues from international markets within the first two years of their existence (although according to some authors exports should start "from inception" (Oviatt \& McDougall, 1994), or from "earliest days" (Knight \& Cavusgil, 1996)),

- $\quad$ the founder has a global vision of markets,

- there is a managerial urge for internationalization through the use of most advanced technologies.

The entrepreneurial attitude of firm founders has been identified by many researchers as the primary factor accelerating the internationalization of firms (McDougal et al., 2003, Knight \& Cavusgil, 1996 and 2004, Madsen and Servais, 1997, Fletcher, 2000; or Simionescu \& Strielkowski, 2017; Idzikowski \& Perechuda, 2018).

Other authors indicated the special role of international strategic alliances or effective use of social and business networks (Rasmussen et al., 2001, Evangelista, 2003, Spence, 2003). Another group of economists in their definitions of born globals stressed on the innovativeness and high willingness to take risks (McDougall \& Oviatt, 2000). Some authors also pointed out the importance of the global vision (Gabrielsson et al., 2008).

In literature, we can also find other terms describing SMEs engaged in the process of early internationalization, e.g., "global start-ups" (Oviatt and McDougall, 1995), "high technology start-ups" (Jolly et al., 1992), and "international new ventures" (Oviatt and McDougall, 1994, Servais \& Rasmussen, 2000, McDougall et al., 2003, Coviello, 2006; Ehrenbergeret al., 2015; Pietrasieński \& Ślusarczyk, 2015; Meyer, et al., 2016; Choquette et. al., 2017).

The latter term is gaining popularity because it is less restrictive ("international") than the one offered by Rennie (1993, implying "globalness"). Moreover, Crick (2009) argues that the terms "born global" (BG) and "international new venture" (INV) are used interchangeably to characterize firms undergoing rapid internationalization "typically but not exclusively within three years of their business start-up". He stressed that the term "global" suggested that the firm operates in at least the world's triad regions. INVs are also characterized by quick expansion of their operations at foreign markets but without the necessity of global presence. This is the case presented in our research: the companies in our sample are active mainly at German market, and also in some other EU countries).

The uniqueness of INVs is emphasized due to their early international expansion in contrast to sequential internationalization captured by the Uppsala model. However, the largesample studies comparing the performance of INVs to later internationalized firms have not been undertaken in the existing literature.

The concept of born globals was first used in Polish literature by Nowakowski (1999). Further research was conducted by Gorynia (2007), Przybylska (2010, 2013), Cieślik (2010), Duliniec (2011), Kowalik and Baranowska-Prokop (2013), Danik and Kowalik (2013 and 2015), Danik et al. (2015), and Baranowska-Prokop and Sikora (2014, 2017). They concentrate on various aspects of early internationalization, but their primary focus is on the general characteristics of Polish INVs, the determinants of their formation, the choice of entry 
mode into foreign markets, the number of markets served, the meaning of psychic distance, managerial attitudes etc.

Analyzing managerial perception, Danik and Kowalik (2015) showed in their qualitative analysis that Polish born-globals perceived product quality and pricing as their main success factors. Moreover, the internal motives for internationalization (proactive motivation for developing international operations) are more important for Polish enterprise owners, than the external, pull factors (Danik et al., 2015).

Baranowska-Prokop and Sikora (2014) found that - within Porter's typology of strategies - the differentiation strategy has been associated with the highest evaluation of Polish INVs market success (as compared to price leadership and "stuck-in-the-middle" strategic situation).

There are two main objectives of the present article. Firstly, to verify the hypotheses concerning relationships between the measures of success and explanatory variables from four conceptual areas. Secondly, to examine the stability of success factors across two measures of success perception: financial situation and success in relation to competitors. The analysis is conducted separately for small-sized companies and for medium-sized firms.

Explanation of success factors is carried out within four research frameworks: "general" management and marketing-mix strategies, M.E. Porter's generic strategies (differentiation versus cost or price leadership), sector-specific determinants, and main export markets determinants.

Our analyses related to the two samples of Polish INVs (collected in 2013, N = 256 and then in 2014, $\mathrm{N}=233$ ) aimed at explaining the perceptions of success by managers as well as the relationship between innovativeness and success perceptions have been previously presented by Baranowska-Prokop and Sikora (2016 and 2017).

As far as the relationship between innovativeness and perception of market success is concerned, Baranowska-Prokop and Sikora (2016) found no significant relationships between both concepts for the two samples of Polish INVs. However, a more detailed analysis considering small and medium-sized enterprises separately (and including supplementary forms of innovations) revealed both direct positive relationship (for innovations in promotion in the latest sample) and the existence of interactions in which small innovative INVs evaluated their success in less favorable terms than the medium-sized innovative ones (in the case of product innovations).

This was the rationale for combining previous theoretical perspectives and performing the analysis for small-sized companies and medium-sized firms separately.

The rest of this paper is organized as follows. In the subsequent part, we present the sample characteristics and our research method. Next, we introduce the hypotheses and discuss the obtained results. Finally, we provide research conclusions and recommendations.

\section{Sample characteristics and research method}

All data have been collected by Indicator Sp. z o.o. (the certified market research company) from February 7th till March 15th, 2013 with the use of CATI method. The sampling frame was GUS (Central Statistical Office) database composed of 18732 Polish manufacturing firms.

The final sample has been selected randomly (allowing for statistical inference) within two strata - small enterprises and medium-sized enterprises under the following conditions: 1) the firm was established not earlier than 1990 (i.e. after the market mechanism replaced the centrally planned economy in Poland), 2) it is not an outcome of M\&A, 3) it is not a branch of a foreign firm, 4) it has not been privatized (i.e. it has not been previously a State-owned 
enterprise), 5) it belongs to sector $\mathrm{C}$ - manufacturing firm (according to PKD classification), 6) it began exporting not later than 3 years after being established, and 7) it has reached at least 25 percent of revenues from exports not later than 3 years after being established and it still (at the date of survey) received at least 25 percent of revenues from exports.

The selection criteria comply with definitions of INVs, but as it was mentioned earlier we prefer to use the last concept as a more general one and because the majority of companies from our sample export their products to Germany and to other European countries.

The final sample comprises 256 firms with the number of employees from 10 to 249 . Small enterprises employing 10-49 people accounted for 52,3 percent of the sample and the medium-size firms employing 50-249 people constituted the remaining 47,7 percent.

The average annual sales revenue was below 2 million euro for 51,6 percent of analyzed firms. The revenues in the range of 2 to 10 million euro were reported by 40,6 percent of enterprises, and the sales of 10 to 50 million were earned by 7,8 percent.

The interviewed people were the company's owners, top managers or managers responsible for the firm's relations with international partners. Among the analyzed firms 40,2 percent were established between 1990 and 1995, 18 percent were launched from 1996 to 2000, and 38,3 percent of enterprises were founded in the period of 2001-2008, and only 3,5 percent were created in the period of recent crisis, i.e., after 2008. According to the market research company which collected the data, the random sampling of enterprises (within two strata: small and medium-sized enterprises) makes it possible to apply statistical inference for the obtained results. Our data were statistically analyzed with the use of SPSS software.

Although the authors have data from two Polish INVs samples, from 2013 and 2014, the first sample has been selected as offering consistently better possibilities in terms of model quality (explained variance) than the second sample. As far as performance of enterprises measured by the success perception, the figures from both samples show similarly high level of INVs whose owners or managers declared that their firms were successful: between 75 per cent and 91 per cent of firms were successful and/or profitable.

\section{Hypotheses development}

The first three hypotheses are based on the management orientation and marketing theoretical frameworks, and on the M. E. Porter's generic competitive strategies approach. Out of many possible management orientation perspectives, items related to international orientation and capabilities of firms' management teams have been included in the questionnaire.

The relationship between early internationalization and economic performance of the firm has been the focus of numerous empirical studies. However, they do not lead to unambiguous conclusions. Sullivan (1994) and Contractor (2007) raise doubts about the results of over 100 studies conducted over the last thirty years.

First of all, the difficulties in comparing the outcomes of research are due to the differences in applied financial indicators, e.g., ROA, ROS, ROE (Ruigrok and Wagner, 2003), market measures, e.g. Tobin's q (Thomas and Eden, 2004), efficiency indicators (Gomes and Ramaswamy, 1999).

Moreover, the research conducted by Halldin (2012) on 230 Swedish enterprises of born-global type confirmed a positive impact of early internationalization on economic performance measured by the increase in employment and sale's revenue. However, after five years of their market activity, the profitability of these firms was not higher than others that are not classified as INVs. General research results do not indicate unequivocally a positive impact of early internationalization on the economic performance of the firm. 
In order to avoid difficulties of this kind in our analysis, we use the concept of managerial perception of success to evaluate the performance of INVs. This approach is subjective in its character but allows to embrace a wider idea of market success. Furthermore, firstly, it is not evident to get viable "hard data" from the SMEs owners or managers on their firms' financial results, secondly, in the case of family-owned SMEs profit maximization, considered as "official" profits declared to fiscal authorities, is not always the main goal of the activity. Therefore, we use two measures of success: in financial terms, and in comparison to competitors.

Our first research hypothesis states that in the case of Polish INVs:

H1. There is a positive relationship between international orientation and international capabilities of top management and the success perception of enterprises.

The marketing-mix tools - known as "4P" - are one of the most commonly accepted concepts in marketing management. For industrial firms producing goods of massconsumption, it takes a form of four marketing strategies: product (and brand) management strategy, price strategy, distribution (or place) strategy and promotion strategy. In other sectors, the number of marketing-mix tools may be greater; e.g. there is a " $7 \mathrm{P}$ " marketing concept for services including additional strategies: people management strategy, process, and physical evidence strategy.

Based on the research within Dynamic Capabilities Theory (Eisenhardt and Martin, 2000, Makadok, 2001), Morgan et. al. (2009) found a positive relationship between marketing capabilities and subjectively, as well as, objectively assessed performance. After reviewing 101 empirical papers, Kamboj and Rahman (2015, p. 1041) stated that: "Product, price, promotion, and distribution found as majorly studied measures of MC (marketing capabilities) with mainly positive and significant impact on FP (financial performance)".

Therefore, we postulate that a proper use of marketing-mix tools is expected to positively influence companies' success. The second hypothesis states that in the case of Polish INVs:

H2. There is a positive relationship between the excellence in the use of marketing-mix tools and the success perception of enterprises.

The classification of competitive strategies proposed by Porter (1992 and 1998) embraces:

- differentiation, i.e., building competitive advantage in chosen areas, e.g., technology, high quality, positive image of firms, strong brands, etc.,

- $\quad$ concentration (or focus), i.e., operating in selected niche markets.

- cost leadership in value chain creation (cost dominance), which leads to a cheaper supply in comparison to the rivals.

It should be noted that the question on the strategy of market concentration has been purposefully excluded by the assumption that the applied basic strategies, i.e., cost leadership, or differentiation are applied by the investigated SMEs which operate in niche markets. According to Porter, the concentration strategy may also be differentiation- or cost leadershiporiented: "The strategy rests on the premise that the firm is thus able to serve its narrow strategic target more effectively or efficiently than competitors who are competing more broadly. As a result, the firm achieves either differentiation from better meeting the needs of the particular target, or lower costs in serving this target (...). Even though the focus strategy does not achieve low cost or differentiation from the perspective of the market as a whole, it does achieve one (...) of these positions vis-à-vis its narrow market target" (Porter, 1998, pp. 38-39).

In our analysis, we presume that there may be no direct (or close) relationship between prices of products and production costs, e.g., dumping, market penetration strategy, prices of 
"accessible" luxury products (various accessories and gadgets with logo of luxury brands), etc. illustrate the cases of no correlation between costs and prices. Therefore, in our research, we focus on the "price leadership" strategy rather than "cost leadership" and consider the two concepts as synonyms.

Using Porter's competitive strategies classification, we conjecture that in the case of Polish INVs:

H3. A clearly-defined strategy (differentiation or price leadership) leads to the higher evaluation of a company's success.

Hypothesis H3 is derived from Porter's description of the stuck-in-the-middle (or stuck-in-between) companies and from his "convexity hypothesis" which implied a U-shaped (or V-shaped) relationship between ROI (return on investment) or profitability and market share (Porter, 1998, p. 43). The issue of market share has not been taken into account in this research since it is less evident in the case of the SMEs. However, since Porter associated the cost-leadership strategy with a considerable market share (Porter, 1998, p. 36) while admitting that the large market share may be incompatible with a differentiation strategy (Porter, 1998, p. 38), his hypothesis can be expressed as: only a singular strategy (either cost leadership or differentiation) can generate a high ROI (high profit or success).

Two additional hypotheses capture the impact of industry type or two main export markets on the success perception in the case of Polish INVs. which they operate.

H4. The success perception of enterprises depends on the branch of industry in

H5. The success perception of enterprises depends on the main export markets in which they operate.

\section{Research results}

\section{Dependent Variable: Perception of Success by Owners and Managers}

The following statements concerning the evaluation of firms' success were posed to Polish international new ventures and born globals to be evaluated on a 5-point Likert scale (the lack of success corresponded to values of 1 and 2 on the scale; the success corresponded to values of 4 or 5 . The respondents were owners, top managers, or managers responsible for international operations and relations with foreign partners):

1. Considering the financial indices (e.g. profitability) for our firm, it can be concluded that our company has been successful.

2. Considering the situation of the (domestic and foreign) markets in which our firm operates, it can be concluded that our company has been successful in comparison to its competitors.

Distribution of answers to the first statement concerning firms' success is shown in Table 1. 
Table 1. Distribution of answers to the first statement concerning firms' success: "Considering the financial indices (e.g. profitability) for our firm, it can be concluded that our company has been successful"

\begin{tabular}{|c|c|c|c|c|c|}
\hline & Responses & Frequency & Percent & Valid Percent & Cumulative Percent \\
\hline \multirow{6}{*}{ Valid } & Definitely not & 4 & 1,6 & 1,6 & 1,6 \\
\hline & Rather not & 12 & 4,7 & 4,7 & 6,3 \\
\hline & Midpoint & 33 & 12,9 & 13,0 & 19,4 \\
\hline & Rather yes & 108 & 42,2 & 42,7 & 62,1 \\
\hline & Definitely yes & 96 & 37,5 & 37,9 & 100,0 \\
\hline & Total & 253 & 98,8 & 100,0 & \\
\hline \multirow{2}{*}{\multicolumn{2}{|c|}{$\begin{array}{l}\text { Missing } \\
\text { Total }\end{array}$}} & 3 & 1,2 & & \\
\hline & & 256 & 100,0 & & \\
\hline
\end{tabular}

Source: own calculations

Distribution of answers to the second statement concerning firms' success is shown in Table 2.

Table 2. Distribution of answers to the second statement concerning firms' success: "Considering the situation on the (domestic and foreign) markets in which our firm operates, it can be concluded that our company has been successful in comparison to its competitors"

\begin{tabular}{llcccc}
\hline & Responses & Frequency & Percent & Valid Percent & Cumulative Percent \\
\hline \multirow{5}{*}{ Valid } & Definitely, not & 6 & 2,3 & 2,4 & 2,4 \\
\cline { 2 - 6 } & Rather not & 6 & 2,3 & 2,4 & 4,8 \\
\cline { 2 - 6 } & Midpoint & 48 & 18,8 & 19,4 & 24,2 \\
\cline { 2 - 6 } & Rather yes & 115 & 44,9 & 46,4 & 70,6 \\
\cline { 2 - 6 } & Definitely, yes & 73 & 28,5 & 29,4 & 100,0 \\
\cline { 2 - 6 } & Total & 248 & 96,9 & 100,0 & \\
\hline Missing & 8 & 3,1 & & \\
\hline Total & 256 & 100,0 & & \\
\hline
\end{tabular}

Source: own calculations

Bigger companies from the sample (employing $50-249$ people) were slightly more successful than the smaller ones (employing $10-49$ people): mean for the first statement are, respectively, 4,22 and 4,00 ( $\mathrm{p}=0,052$ for t-Student test and $\mathrm{p}=0,068$ for Mann - Whitney $\mathrm{U}$ test) and for the second statement differences are non-significant: 3,89 and 4,08, respectively, although they go in the same direction ( $p=0,107$ for $\mathrm{t}$-Student test and $\mathrm{p}=0,126$ for Mann Whitney $U$ test). Correlation between both measures of success is moderate: $r=0,47, \rho=$ 0,441 .

Among successful companies, the majority of respondents declared that their companies had achieved a moderate success, "rather" agreeing with the above statements. It should be noted that respondents from only a few firms admitted the lack of success in financial terms (less than 7 percent) or compared to competitors, both in Poland and abroad (less than 5 percent). This may result from the unwillingness of respondents representing unsuccessful companies to agree to be interviewed (the market research company did not confirm that fact), or from the fact, a macroeconomic factor might have played a role. As it has been pointed out: "the weakest firms went out of business due to 2008 crisis as highly export-dependent Born globals were strongly exposed to the contraction of global demand" (Baranowska-Prokop, Sikora, 2014, p. 111) and difficulties or bankruptcies among importers from export markets. 
Apart from the 2008-crisis elimination of the worst managed companies, the success of those which were selected into our sample might have been boosted by another macroeconomic factor, i.e., depreciated Polish currency (after August 2008).

\section{Independent Variables: Management International Orientation and Marketing-Mix Strategies}

As far as "general" management orientations are concerned, items expressing international orientation and capabilities of managerial team to act on foreign markets have been included into the questionnaire with the following items measured on a 5-point semantic differential-like scales (marked [1] or [5] at the end of each statement in the tables): "In our company, we look for new market opportunities more often abroad rather than domestically In our firm, we look for new market opportunities more often domestically rather than abroad", "The management is experienced in running business in international markets - The management has no experience in running business in international markets".

Marketing-mix perspective has been taken into account by introducing questions (measured on two-point "yes-no" scales: "Is your company introducing any innovations, or develops new technologies?", marked [0:1] in the tables) and variously expressed items (measured on 5-point Likert scales, marked [1:5] in the tables or on semantic differential-like scales marked [1] or [5] at the end of each statement) concerning each of four "4P" strategies: product and brand strategy, price strategy, distribution strategy and promotion strategy. Product and brand-related strategies have been taken into account from many aspects: innovativeness ("Our firm is superior in terms of product development and/or adaptation in comparison to its competitors"), technological superiority ("Our products are more technologically advanced than the products of our competitors - Our products are less technologically advanced than the products of our competitors'), quality ("We compete on the foreign markets primarily through high quality"), similarity to and substitutability by competitor's products (examples are given hereafter), etc. Three remaining marketing-mix strategies have been analyzed with separate items (i. e. "Our firm is superior in terms of distribution effectiveness in comparison to its competitors").

In all but one cases 5-point interval scales are used as measures of both independent and dependent variables. This allows for the formulation "excellence in the use of marketingmix tools" in hypothesis 2 instead of merely "the use of marketing-mix tools", because it is possible to take into account differences between the "definitely" and "rather" agreements and disagreements by respondents with the items formulations.

The hypothesis testing will be performed by building and analyzing linear regression models. The models will allow assessing the contribution of microeconomic variables (industry type and main export markets) to the explanation of the success perception beyond the management and marketing-related variables. In each case, the "stepwise forward selection" method has been used to build the models (and only "forward-selected" variables are included). In the process of hypotheses' testing, application of the stepwise selection method in elaborating regression models should be considered as more restrictive procedure than correlation analysis or elaboration of series of simple regression models for each of variables separately. This is due to the fact that the models contain only those variables that contribute in the best way of explaining the independent variables (i.e., the success perception measures). Moreover, stepwise methods help to eliminate multicollinearity problems.

Table 3 presents the regression model based on management and marketing-mix variables for small enterprises concerning the first measure of success. 
Table 3. Linear regression model for the first measure of success, small companies (without two outliers), management and marketing-related variables

\begin{tabular}{|c|c|c|c|c|c|}
\hline \multirow[t]{2}{*}{ Model } & \multicolumn{2}{|c|}{$\begin{array}{l}\text { Unstandardized } \\
\text { Coefficients } \\
\end{array}$} & \multirow{2}{*}{$\begin{array}{c}\begin{array}{c}\text { Standardized } \\
\text { Coefficients }\end{array} \\
\text { Beta } \\
\end{array}$} & \multirow[t]{2}{*}{$\mathrm{T}$} & \multirow[t]{2}{*}{ Sig. } \\
\hline & $\mathrm{B}$ & Std. Error & & & \\
\hline (Constant) & 2,185 &, 353 & & 6,189 & 000 \\
\hline $\begin{array}{l}\text { 1. Our firm is superior in terms of the speed } \\
\text { of introduction of new products to the market } \\
\text { in comparison to its competitors [1:5] }\end{array}$ & ,345 & ,068 & ,414 & 5,083 & ,000 \\
\hline $\begin{array}{l}\text { 2. Introduction or not of innovations and/or } \\
\text { new technologies }[0: 1]\end{array}$ &,- 524 & ,153 &,- 281 & $-3,427$ & ,001 \\
\hline $\begin{array}{l}\text { 3. In our firm, the most important issues are } \\
\text { cost savings and continuous cost reduction [1] } \\
\text { - In our firm, the issues of cost savings and } \\
\text { continuous cost reduction are not the most } \\
\text { important [5] }\end{array}$ & 166 & ,051 & 254 & 3,256 & ,001 \\
\hline $\begin{array}{l}\text { 4. We compete on the foreign markets } \\
\text { primarily through low prices }[1: 5]\end{array}$ & 136 & ,057 & 186 & 2,370 & 019 \\
\hline
\end{tabular}

\section{Source: own calculations}

Table 4 presents the regression model obtained with management and marketing-mix variables for small enterprises concerning the second measure of success.

Table 4. Linear regression model for the second measure of success, small companies (without five outliers), management and marketing-related variables

\begin{tabular}{|c|c|c|c|c|}
\hline \multirow[t]{2}{*}{ Model } & \multicolumn{2}{|c|}{$\begin{array}{l}\text { Unstandardized } \\
\text { Coefficients }\end{array}$} & \multirow{2}{*}{$\begin{array}{c}\text { Standardized } \\
\text { Coefficients } \\
\text { Beta } \\
\end{array}$} & \multirow[t]{2}{*}{ T Sig. } \\
\hline & $\mathrm{B}$ & Std. Error & & \\
\hline (Constant) &,- 022 & ,493 & & $-, 044,965$ \\
\hline $\begin{array}{l}\text { 1. We compete on the foreign markets primarily through high } \\
\text { quality [1:5] }\end{array}$ & ,974 & , 157 & ,448 & 6,207, 000 \\
\hline $\begin{array}{l}\text { 2. Our basic export product has many substitutes [1] - Our } \\
\text { basic export product has no substitutes [5] }\end{array}$ & , 145 & ,041 & ,249 & $3,547,001$ \\
\hline $\begin{array}{l}\text { 3. Our firm is superior in terms of product development } \\
\text { and/or adaptation in comparison to its competitors [1:5] }\end{array}$ & ,227 & ,066 & ,248 & 3,443, 001 \\
\hline $\begin{array}{l}\text { 4. We compete on the foreign markets primarily through low } \\
\text { prices }[1: 5]\end{array}$ & , 127 & ,047 & , 187 & 2,687, 008 \\
\hline $\begin{array}{l}\text { 5. The management is experienced in running business in } \\
\text { international markets [1] - The management has no } \\
\text { experience in running business in international market [5] }\end{array}$ &,- 150 & ,065 &,- 165 & $-2,319,022$ \\
\hline $\begin{array}{l}\text { 6. In our company, we look for new market opportunities } \\
\text { more often abroad rather than domestically [1]- In our firm, } \\
\text { we look for new market opportunities more often } \\
\text { domestically rather than abroad [5] }\end{array}$ &,- 100 & ,048 &,- 147 & $-2,065,041$ \\
\hline
\end{tabular}

a. Dependent Variable: Success compared to competitors; R-square $=0,463$; Adj. R-square $=0,434 ; d=2,284$; residuals do not significantly depart from normal distribution.

Source: own calculations

Comparing the two models we can notice an instability of success factors since mostly distinct variables have been identified for each measure of success. 
International orientation measured by "international" capabilities of top managers and orientation on foreign markets is positively related to the second measure of success, thus partially confirming $\mathrm{H} 1$ (the regression coefficients are negative for positive relationships due to reverse coding of the scales).

Competing with low prices is in both models positively, albeit weakly correlated with the perception of success, but the "not-cost-saving" policy is positively correlated in the model for the first measure of the success (this is not consistent with the logic that competing with low prices should be associated with tight control of costs). As far as innovativeness and technological superiority is concerned, the companies which didn't introduce any innovations declared greater success expressed by the first measure of success. However, the innovative companies, by being superior over competitors in product development capabilities or other companies developing non-innovative, "me-too" products achieved greater success according to both measures. The high quality of products is positively correlated with the second measure of success.

Taking this into consideration $\mathrm{H} 2$ is partially confirmed (in the case of product development strategies, regardless they are innovative or not, and for high quality of products) and partially disconfirmed as the abstention from innovations seems to be more favorable for small INVs than introducing them and as competing with low prices while producing goods of high quality looks like underutilization of marketing potential.

Table 5 presents regression models based on management and marketing-mix variables for medium-sized enterprises concerning the first measure of success.

Table 5. Linear regression model for the first measure of success, medium-sized companies (without one outlier), management and marketing-related variables

\begin{tabular}{|c|c|c|c|c|c|}
\hline \multirow{2}{*}{ Model } & \multicolumn{2}{|c|}{$\begin{array}{l}\text { Unstandardized } \\
\text { Coefficients }\end{array}$} & \multirow{2}{*}{$\begin{array}{c}\begin{array}{c}\text { Standardized } \\
\text { Coefficients }\end{array} \\
\text { Beta }\end{array}$} & \multirow[t]{2}{*}{$\mathrm{T}$} & \multirow[t]{2}{*}{ Sig. } \\
\hline & $\mathrm{B}$ & $\begin{array}{l}\text { Std. } \\
\text { Error }\end{array}$ & & & \\
\hline (Constant) & 2,682 & ,545 & & 4,924 & ,000 \\
\hline $\begin{array}{l}\text { 1. Our firm is superior in terms of product } \\
\text { development and/or adaptation in comparison to its } \\
\text { competitors [1:5] }\end{array}$ & ,270 & ,073 & ,309 & 3,671 & ,000 \\
\hline $\begin{array}{l}\text { 2. Our products are significantly similar to the ones } \\
\text { offered by the competitors [1] - Our products are } \\
\text { significantly different from the ones offered by the } \\
\text { competitors [5]. }\end{array}$ &,- 178 & ,066 &,- 227 & $-2,697$ & ,008 \\
\hline $\begin{array}{l}\text { 3. We compete on the foreign markets primarily } \\
\text { through high quality [1:5] }\end{array}$ & ,284 & ,123 & ,194 & 2,305 & ,023 \\
\hline
\end{tabular}

Source: own calculations

Table 6 presents regression models obtained with management and marketing-mix variables for medium-sized enterprises for the second measure of success. 
Table 6. Linear regression model for the second measure of success, medium-sized companies (without three outliers), management and marketing-related variables

\begin{tabular}{|c|c|c|c|c|}
\hline \multirow[t]{2}{*}{ Model } & \multicolumn{2}{|c|}{$\begin{array}{l}\text { Unstandardized } \\
\text { Coefficients }\end{array}$} & \multirow{2}{*}{$\begin{array}{c}\begin{array}{c}\text { Standardized } \\
\text { Coefficients }\end{array} \\
\text { Beta }\end{array}$} & \multirow[t]{2}{*}{$\mathrm{t} \quad$ Sig. } \\
\hline & B & Std. Error & & \\
\hline (Constant) & 1,793 &, 435 & & $4,121,000$ \\
\hline $\begin{array}{l}\text { 1. We compete on the foreign markets primarily through high } \\
\text { quality }[1: 5]\end{array}$ & ,476 & ,111 & ,369 & $4,296,000$ \\
\hline $\begin{array}{l}\text { 2. Our firm is superior in terms of product development and/or } \\
\text { adaptation in comparison to its competitors }[1: 5]\end{array}$ & , 177 & ,066 & ,231 & $2,684,008$ \\
\hline
\end{tabular}

Source: own calculations

Unlike in the case of small firms, the success factors have been relatively stable in the case of the medium-sized ones: high-quality goods (with few substitutes, preferably) and good capabilities in product development were positively correlated with both measures of the success perception, thus confirming H2. International orientation is "absent" as it does not seem to explain, independently of the product policy, the success in either of models.

However, the explanatory power of these models is weaker compared to the case of small enterprises, as R-square is between 0,2 and 0,25 .

\section{Independent Variables: Competitive Strategies - M. E. Porter's Framework}

The Porter's framework: differentiation - cost/price leadership has been reflected by four variables:

- product similarity ("Our products are significantly similar to the ones offered by the competitors - Our products are significantly different from the ones offered by the competitors"),

- product substitutability ("Our basic export product has many substitutes- Our basic export product has no substitutes") - both expressing the differentiation strategy,

- price competition 1 ("The prices of our basic export product are the lowest on the market - The prices of our basic export product are the highest on the market") and

- price competition 2 ("We compete on the foreign markets primarily through low prices") - both expressing price-leadership strategy.

The idea of Porter's framework is to look at U- or V-shaped relationships between strategies and firms' success (the convexity hypothesis) as firms applying differentiation or price-leadership strategy should be better off than the firms applying none of them (the stuckin-the-middle situation).

Therefore, we propose a special measurement procedure which makes it possible to analyze non-linear relationships to the full extent. The identified four variables have been converted into a binary form in the following manner:

- for the product similarity measure, answers " 1 ", i.e. "strongly agree that products are significantly similar", have been named "Strong non-differentiation 1", for the "rather agree" - "Rather non-differentiation 1, answers "neither-nor" - "Stuck-in-the middle 1", answers "rather agree that is different" - "Rather differentiation 1" and the "strongly agree that products are significantly different" - "Strong differentiation 1";

- for the product substitutability measure, similarly, also five binary variables have been obtained: "Strong non-differentiation 2", "Rather non-differentiation 2", Stuck-in-themiddle 2", "Rather differentiation 2" and "Strong differentiation 2";

- for the price competition 1, answers strongly agreeing that prices of basic export products are the lowest on the market have been transformed into "Strong price 
leadership 1", then "Rather price leadership 1, "Stuck-in-the middle 3", and for the agreements that prices of companies' products are the highest on the market: "Rather not price leadership 1" and "Strong not-price leadership 1";

- for the price competition 2 also five variables have been created: "Strong price leadership 2", "Rather price leadership 2", Stuck-in-the middle 4", "Rather not price leadership 2" and "Strong not price leadership 2".

The "no differentiation" does not mean "price leadership" and "not price leadership" does not mean "differentiation", in most cases because there are very weak or no correlations between variables from the two different registers. This may suggest an opening discussion about cohesion and coherence (or lack thereof) in thinking and responding by entrepreneurs and managers or on insufficiency of Porter's triadic framework (i.e. differentiation, cost leadership and stuck-in-the middle case).

Table 7 presents correlation coefficients for the first measure of success obtained with Porter's framework variables for small enterprises (only significant correlations are reported).

Table 7. Correlations for the first measure of success, small companies (without one outlier), Porter's framework

Kendall's tau b

Considering the financial indices (e.g. profitability) for our firm, it can be concluded that our company has been successful

\begin{tabular}{|c|c|c|}
\hline & & \\
\hline \multirow{3}{*}{$\begin{array}{l}\text { Strong not price } \\
\text { leadership } 2\end{array}$} & Correlation Coefficient &,$- 222^{* * *}$ \\
\hline & Sig. (2-tailed) &, 007 \\
\hline & $\mathrm{N}$ & 131 \\
\hline \multirow[t]{3}{*}{ Strong differentiation 2} & Correlation Coefficient & ,234 ${ }^{* *}$ \\
\hline & Sig. (2-tailed) &, 004 \\
\hline & $\mathrm{N}$ & 131 \\
\hline
\end{tabular}

**. Correlation is significant at the 0.01 level (2-tailed).

Source: own calculations

Table 8 provides correlation coefficients for the second measure of success obtained with Porter's framework variables for small enterprises.

Table 8. Correlations for the second measure of success, small companies (without two outliers), Porter's framework

\begin{tabular}{llr}
\hline \multirow{2}{*}{ Kendall's tau b } & $\begin{array}{c}\text { Considering the situation on the (domestic and foreign) markets, } \\
\text { where our firm operates, it can be concluded that our company has } \\
\text { been successful in comparison to its competitors }\end{array}$ \\
\hline $\begin{array}{l}\text { Strong } \\
\text { differentiation }\end{array}$ & Correlation Coefficient & \\
\cline { 2 - 3 } & Sig. (2-tailed) &, $\mathbf{2 4 6}^{* * *}$ \\
\cline { 2 - 3 } $\begin{array}{l}\text { Strong price } \\
\text { leadership } 2\end{array}$ & Correlation Coefficient &, 003 \\
\cline { 2 - 3 } & Sig. (2-tailed) & $\mathbf{1 6 9}^{*}$ \\
\hline
\end{tabular}

**. Correlation is significant at the 0.01 level (2-tailed).

*. Correlation is significant at the 0.05 level (2-tailed).

Source: own calculations

Table 9 presents correlation coefficients for the first measure of success obtained with Porter's framework variables for medium-sized enterprises. 
Table 9. Correlations for the first measure of success, medium-sized enterprises (without eight outliers), Porter's framework

\begin{tabular}{|c|c|c|}
\hline Kendall's tau b & & $\begin{array}{l}\text { Considering the financial indices (e.g. profitability) for our } \\
\text { firm, it can be concluded that our company has been } \\
\text { successful }\end{array}$ \\
\hline Strong not price & Correlation Coefficient & ,328** \\
\hline \multirow[t]{2}{*}{ leadership 2} & Sig. (2-tailed) &, 000 \\
\hline & $\mathrm{N}$ & 113 \\
\hline \multirow[t]{3}{*}{ Strong differentiation 2} & Correlation Coefficient & ,276 \\
\hline & Sig. (2-tailed) &, 002 \\
\hline & $\mathrm{N}$ & 113 \\
\hline \multirow{3}{*}{$\begin{array}{l}\text { Strong non- } \\
\text { differentiation } 2\end{array}$} & Correlation Coefficient &, $235^{* * *}$ \\
\hline & Sig. (2-tailed) &, 010 \\
\hline & $\mathrm{N}$ & 113 \\
\hline \multirow[t]{3}{*}{ Stuck-in-the-middle 2} & Correlation Coefficient &,$- \mathbf{2 2 8}$ \\
\hline & Sig. (2-tailed) &, 013 \\
\hline & $\mathrm{N}$ & 113 \\
\hline
\end{tabular}

**. Correlation is significant at the 0.01 level (2-tailed).

*. Correlation is significant at the 0.05 level (2-tailed).

Source: own calculations

Table 10 presents correlations for the second measure of success obtained with Porter's framework variables for medium-sized enterprises.

Table 10. Correlations for the second measure of success, medium-sized enterprises (without two outliers), Porter's framework

\begin{tabular}{|c|c|c|}
\hline Kendall's tau b & & $\begin{array}{l}\text { Considering the situation on the (domestic and } \\
\text { foreign) markets, where our firm operates, it can be } \\
\text { concluded that our company has been successful in } \\
\text { comparison to its competitors }\end{array}$ \\
\hline \multirow[t]{3}{*}{ Strong differentiation 2} & Correlation Coefficient & ,255 \\
\hline & Sig. (2-tailed) &, 004 \\
\hline & $\mathrm{N}$ & 117 \\
\hline \multirow[t]{3}{*}{ "Rather" differentiation 2} & $\overline{\text { Correlation Coefficient }}$ &,$- 221^{*}$ \\
\hline & Sig. (2-tailed) &, 012 \\
\hline & $\mathrm{N}$ & 117 \\
\hline \multirow[t]{3}{*}{ Stuck-in-the-middle 2} & Correlation Coefficient &,$- 184^{*}$ \\
\hline & Sig. (2-tailed) &, 037 \\
\hline & $\mathrm{N}$ & 117 \\
\hline
\end{tabular}

**. Correlation is significant at the 0.01 level (2-tailed).

*. Correlation is significant at the 0.05 level (2-tailed).

Source: own calculations

The only variable, positively correlated with both measures of success in the four models based on Porter's theory is "strong differentiation 2" related to lack of substitutes for the export products.

The H3 may be considered as not confirmed. It would be confirmed if in all models Ushaped relationships were obtained, i.e. if both "strong" differentiation and price leadership strategies (and eventually "strong" non-differentiation and non-price leadership strategies) were positively correlated with success perceptions and if in all four "stuck-in-the-middle" situations there were negative correlations between the two measures of success perception. 
It should also be noted that the outlier removal procedure led, in most cases, to the exclusion of firms which "strongly" or "rather" disagreed with the "success" statements (tables 1 and 2). Therefore, the above models (in tables 3 to 10) capture mainly three groups of firms: highly successful, moderately successful and those which declared they were "neither successful - nor unsuccessful".

\section{Independent Variables: Industry Type and Main Export Markets}

As far as the first (main) foreign market is concerned, for the small INVs the highest rank indicated by 41 percent of respondents was occupied by Germany. The second place belongs to Russia (8,2 percent), followed by USA (6,7 percent), Great Britain (6,0 percent), Italy (4,5 percent).

The second major export target market indicated by this group of firms was: Germany (9,7 percent), the Netherlands (6,7 percent), Ukraine (6,0 percent), Sweden (5,2 percent).

It should be stressed that as high number as 22,4 percent of Polish small INVs are limiting their exports to just one foreign market.

In the group of medium-sized INVs (50-249 employees) as high as nearly 50 percent of respondents indicated Germany as the main export target market. The second place with a substantially lower fraction (10,7 percent) was occupied by Russia followed by Czech Republic (4,9 percent), France (4,1 percent), the Netherlands (4,1 percent), Great Britain (3,3 percent).

When considering the second major export target market for Polish medium-sized INVs, we found that the first place was occupied by Germany, indicated by 10 percent of respondents. The second place was taken by Great Britain (6,6 percent), followed by the Czech Republic (6,6 percent), Russia (6,6 percent), France (5,7 percent). It should be stressed that in this group of firms, as high as 18,9 percent of respondents reported only one export target market.

The full linear regression models will not be presented as it was in the case of management and marketing-related variables, for the conciseness reasons and because of the fact that they are supposed to play an additional role, as explanatory "supplements". Therefore, it is not important that a particular industrial branch or market has been selected into the model for being significantly different from the rest of branches or markets because it is only important to assess the usefulness of including analysis by branches or markets together with management strategies.

Modeling based on industrial branches gave the following results (branches and markets have been transformed into binary variables, the procedure of stepwise regression, forward selection has been used): the "best model" (out of four modeling cases) was obtained for the second measure of success (without six outliers), for small enterprises: four branches selected, all coefficients negative, R-square $=0,376 ;$ Adj. R-square $=0,355 ; \mathrm{d}=1,875$; residuals significantly depart from normal distribution (what is evident for linear regression models with binary variables only).

Modeling based on main export markets gave the best results for the first measure of success for medium-sized enterprises: eight markets selected, all coefficients negative, Rsquare $=0,350 ;$ Adj. $\mathrm{R}$-square $=0,303 ; \mathrm{d}=1,994$; residuals significantly depart from normal distribution.

The results of linear regression analyses confirm hypotheses 4 and 5: industrial branches and markets played a significant role in explaining the two measures of success perception both in the case of small and medium enterprises.

Thus, the analysis of success perception based on industrial branches and markets leads to similar or even better results (in terms of R-square statistics) as the analysis based on management and marketing-related variables. 


\section{Final Composite Models}

The final models built with the use of variables based on all four frameworks are presented below.

Table 11 shows a composite model for small enterprises concerning the first measure of success.

Table 11. Linear regression - a composite model for the first measure of success, small enterprises (without one outlier) ${ }^{\mathrm{a}}$

\begin{tabular}{|c|c|c|c|c|c|}
\hline \multirow{2}{*}{ Model } & \multicolumn{2}{|c|}{$\begin{array}{l}\text { Unstandardized } \\
\text { Coefficients }\end{array}$} & \multirow{2}{*}{$\begin{array}{c}\text { Standardized } \\
\text { Coefficients } \\
\text { Beta }\end{array}$} & \multirow{2}{*}{$\mathrm{t}$} & \multirow{2}{*}{ Sig. } \\
\hline & B & $\begin{array}{l}\text { Std. } \\
\text { Error }\end{array}$ & & & \\
\hline (Constant) & 3,064 & ,301 & & 10,186 & ,000 \\
\hline $\begin{array}{l}\text { 1. Our firm is superior in terms of the speed of } \\
\text { introduction of new products to the market in } \\
\text { comparison to its competitors [1:5] }\end{array}$ &, 279 & 068 & ,322 & 4,068 &, 000 \\
\hline $\begin{array}{l}\text { 2. Introduction or not of innovations and/or new } \\
\text { technologies [0:1] }\end{array}$ &,- 530 & , 151 &,- 274 & $-3,511$ & 001 \\
\hline 3. Strong not price leadership 2 &,- 711 & 234 &,- 234 & $-3,034$ & 003 \\
\hline 4. Denmark (first major export market) & $-1,399$ & 485 &,- 216 & $-2,883$ &, 005 \\
\hline $\begin{array}{l}\text { 5. In our firm, the most important issues are cost } \\
\text { savings and continuous cost reduction [1] - In } \\
\text { our firm, the issues of cost savings and } \\
\text { continuous cost reduction are not the most } \\
\text { important [5] }\end{array}$ &, 130 & ,051 & ,191 & 2,537 & ,012 \\
\hline 6. China (first major export market) & $-1,780$ & ,870 &,- 160 & $-2,046$ & ,043 \\
\hline
\end{tabular}

a. Dependent Variable: Success in financial terms; R-square $=0,354 ;$ Adj. R-square $=0,322 ; d=$ 2,037; residuals do not significantly depart from normal distribution.

\section{Source: own calculations}

According to Table 11, there is an already described contradiction: firms introducing no innovations declared greater success, but for those which introduced innovations the success was positively correlated with the superiority over competitors as far as the speed of introductions of new products was concerned. Possible failures on selected export markets (negative regression coefficients) had some explanatory value, but marketing variables are predominant.

Table 12 presents a composite model for small enterprises concerning the second measure of success. 
Table 12. Linear regression - a composite model for the second measure of success, small enterprises (without two outliers) ${ }^{\mathrm{a}}$

\begin{tabular}{|c|c|c|c|c|c|}
\hline \multirow{2}{*}{ Model } & \multicolumn{2}{|c|}{$\begin{array}{l}\text { Unstandardized } \\
\text { Coefficients }\end{array}$} & \multirow{2}{*}{$\begin{array}{c}\begin{array}{c}\text { Standardized } \\
\text { Coefficients }\end{array} \\
\text { Beta }\end{array}$} & \multirow{2}{*}{$\mathrm{t}$} & \multirow{2}{*}{ Sig. } \\
\hline & B & $\begin{array}{l}\text { Std. } \\
\text { Error }\end{array}$ & & & \\
\hline (Constant) & ,547 &, 446 & & 1,227 & ,222 \\
\hline $\begin{array}{l}\text { 1. We compete on the foreign markets primarily through } \\
\text { high quality [1:5] }\end{array}$ & ,993 & , 149 & ,418 & 6,683 & ,000 \\
\hline 2. China (first major export market) & $-2,750$ & ,702 &,- 251 & $-3,920$ &, 000 \\
\hline 3. Production of leather $\&$ tanned leather articles & $-2,157$ & ,472 &,- 278 & $-4,573$ &, 000 \\
\hline 4. Strong differentiation 2 & 615 & ,155 & ,243 & 3,972 &, 000 \\
\hline $\begin{array}{l}\text { 5. The management is experienced in running business in } \\
\text { international markets [1] - The management has no } \\
\text { experience in running business in international market [5] }\end{array}$ &,- 180 & 064 &,- 181 & $-2,811$ & ,006 \\
\hline 6. Mongolia (second major export market) & $-2,442$ & ,663 &,- 223 & $-3,683$ &, 000 \\
\hline 7. Rubber \& synthetic materials &,- 595 & 188 &,- 193 & $-3,159$ &, 002 \\
\hline $\begin{array}{l}\text { 8. Our firm is superior in terms of product development } \\
\text { and/or adaptation in comparison to its competitors [1:5] }\end{array}$ & ,207 & ,064 & ,207 & 3,247 & ,002 \\
\hline 9. France (first major export market) & ,802 &, 300 & ,162 & 2,673 & 009 \\
\hline
\end{tabular}

a. Dependent Variable: Success compared to competitors; R-square $=0,596$; Adj. R-square $=0,564 ; \mathrm{d}$ $=2,255$; residuals do not significantly depart from normal distribution.

Source: own calculations

As it follows from Table 12, in addition to the important role of management and marketing factors, the branches and main export markets significantly contribute to the explanatory power of the model. The issue of strong differentiation (approached "indirectly" as strong not price leadership in Table 11) is common to both models. Including industrial branches and main export markets into the analysis enabled to reduce the number of outliers.

Table 13 presents a composite model for medium-sized enterprises for the first measure of success.

Table 13. Linear regression - a composite model for the first measure of success, mediumsized companies (without seven outliers) ${ }^{\mathrm{a}}$

\begin{tabular}{|c|c|c|c|c|c|}
\hline \multirow[t]{2}{*}{ Model } & \multicolumn{2}{|c|}{$\begin{array}{l}\text { Unstandardized } \\
\text { Coefficients }\end{array}$} & \multirow{2}{*}{$\begin{array}{c}\text { Standardized } \\
\text { Coefficients } \\
\text { Beta }\end{array}$} & \multirow[t]{2}{*}{$\mathrm{T}$} & \multirow[t]{2}{*}{ Sig. } \\
\hline & $\mathrm{B}$ & Std. Error & & & \\
\hline (Constant) & 2,452 &, 341 & & 7,191 &, 000 \\
\hline 1. Sweden (first major export market) & $-2,296$ &, 532 &,- 286 & $-4,312$ &, 000 \\
\hline $\begin{array}{l}\text { 2. We compete on the foreign markets primarily } \\
\text { through high quality [1:5] }\end{array}$ & ,334 & ,086 & 254 & 3,875 &, 000 \\
\hline 3. Production of cars and trailers & $-1,396$ & ,364 &,- 245 & $-3,833$ &, 000 \\
\hline 4. Ukraine (first major export market) & $-1,149$ & ,302 &,- 245 & $-3,803$ &, 000 \\
\hline 5. Production of medication \& pharmaceuticals & $-1,891$ & ,517 &,- 235 & $-3,661$ &, 000 \\
\hline $\begin{array}{l}\text { 6. Our firm is superior in terms of product development } \\
\text { and/or adaptation in comparison to its competitors [1:5] }\end{array}$ &, 183 &, 053 & ,233 & 3,439 & ,001 \\
\hline 7. Metal production &,- 485 & ,146 &,- 220 & $-3,319$ &, 001 \\
\hline 8. Strong differentiation 2 & 598 & 181 & ,219 & 3,299 & 001 \\
\hline 9. Strong non-differentiation 2 & 251 &, 100 &, 170 & 2,521 & ,013 \\
\hline 10. Romania (first major export market) & $-1,042$ &, 512 &,- 130 & $-2,037$ &, 044 \\
\hline 11. Canada (second major export market) & $-1,078$ &, 525 &,- 134 & $-2,054$ & ,043 \\
\hline
\end{tabular}

a. Dependent Variable: Success in financial terms; R-square $=0,612$; Adj. R-square $=0,568 ; d=1,802$; residuals do not significantly depart from normal distribution.

Source: own calculations 
According to Table 13, marketing-mix is present through the product policy (quality, product development). Porter's framework indicates the positive side of either strong differentiation or - less directly - strong focus product standardization (expressed "indirectly" as strong non-differentiation). Taking into consideration the "export markets" and "industrial branches" perspectives increased substantially explanatory power of the model (Adj. R-square $=0,568$ ) compared to the models in the table 5 (Adj. R-square $=0,219$ ) and table 9 (Adj. Rsquare $=0,222$ ). Seven outliers have been excluded, but this composite model without two outliers only also has better explanatory power than the management- and marketing-based models for the medium-sized companies, because of the Adj. R-Square equals 0,477.

Table 14 presents a composite model for medium-sized enterprises for the second measure of success.

Table 14. Linear regression - a composite model for the second measure of success, mediumsized enterprises (without one outlier) ${ }^{\mathrm{a}}$

\begin{tabular}{|c|c|c|c|c|c|}
\hline \multirow[t]{2}{*}{ Model } & \multicolumn{2}{|c|}{$\begin{array}{l}\text { Unstandardized } \\
\text { Coefficients }\end{array}$} & \multirow{2}{*}{$\begin{array}{c}\text { Standardized } \\
\text { Coefficients } \\
\text { Beta }\end{array}$} & \multirow[t]{2}{*}{$\mathrm{t}$} & \multirow[t]{2}{*}{ Sig. } \\
\hline & $\mathrm{B}$ & Std. Error & & & \\
\hline (Constant) & 1,861 & ,439 & & 4,243 &, 000 \\
\hline $\begin{array}{l}\text { 1. We compete on the foreign markets primarily through } \\
\text { high quality }[1: 5]\end{array}$ &, 480 &, 111 & ,336 & 4,323 &, 000 \\
\hline 2. Denmark (first major export market) & $-2,014$ & 476 &,- 326 & $-4,228$ & ,000 \\
\hline 3. Estonia (second major export market) & $-2,701$ & 674 &,- 310 & $-4,006$ & ,000 \\
\hline 4. "Rather" differentiation 2 &,- 608 & ,192 &,- 242 & $-3,161$ & ,002 \\
\hline $\begin{array}{l}\text { 5. Our firm is superior in terms of product development } \\
\text { and/or adaptation in comparison to its competitors }\end{array}$ &, 176 & ,067 & ,207 & 2,644 & ,009 \\
\hline
\end{tabular}

a. Dependent Variable: Success compared to competitors; R-square = 0,368; Adj. R-square = 0,339; $d=2,084$; residuals do not significantly depart from normal distribution.

\section{Source: own calculations}

As it follows from Table 14, taking into account the branch-export market perspective did not increase the model adjustment in such a spectacular way for the second measure of success as it has been observed in the case of the first measure. The product quality issue is present as the main explanatory variable also for this measure of success replacing strong differentiation as the success driver.

The reason for the important role of the branch-main export markets perspective may be subject to various interpretations. The two elements have been introduced to regression models as binary variables without asking managers concerning their evaluations about the situation in particular industries or export markets. Mostly negative regression coefficients are associated with branches or markets selected for the models. This may be due to the fact that a particular industry was in difficulty or there was a "disaster" in a major export market. For the export markets we may argue that, firstly, failures on main export markets may have influenced the success evaluations by managers more strongly than successes elsewhere, and secondly, in future research, for firms active on several markets when success is evaluated subjectively, questions about successes and failures may address the diversity of achievements on particular markets.

In the situation when the distribution of management and marketing-mix variables has also been skewed towards "self-assessed-as-good" product, price, promotion, and distribution strategies, the difficult situation or failure on main export markets might have been due to the factors not considered in our analysis (macroeconomic or behavioral factors). 


\section{Conclusion and recommendations}

The success factors in the internationalization process of SMEs have been discussed since the early 1990s, but there was no extensive quantitative analysis of factors affecting success perception for the case of Polish INVs. The main objective of this paper was to explain two forms of success perception - the success in financial terms and the success in relation to competitors - declared by respondents from a sample of 256 Polish international new ventures. We conducted our research within four basic frameworks: management international orientation and marketing-mix tools, Porter's competitive strategies, industrial branches and main export markets. Analysis has been performed separately for small- and medium-sized companies.

The additional aim of this paper was to analyze the stability of the success factors across two categories of firms (small and medium-sized firms) and two measures of the success perception.

The majority of analyzed companies declared that they were rather or very successful. The percentages of success declaration amounted to 79,7 for the first measure of success (financial results), and to 73,4 for the second measure (in comparison to competitors).

We may conclude that the relationships revealed in the regression models are mostly weak. The standardized coefficients in the regression models are between 0,2 and 0,4 for the management and marketing variables in most cases. The weak relationships may be due to the distribution of success perception measures: their strong skewness towards success and an insufficient number of unsuccessful firms in the randomly selected sample. The high success rate may be the result of a favorable macroeconomic environment for the exporters, i.e. depreciated (and/or undervalued) domestic currency before and at the moment of interviews and indicates the importance to include macroeconomic conditions and regulations (exchange rate, interest rates, absolute and relative labor costs, export assistance, etc.) in the research on the results of management strategies of exporting firms.

The first hypothesis is partially and weakly confirmed in one out of four cases because there were weak positive correlations between two items expressing international orientation, management capabilities and success perceptions solely for small companies and second measure of success. In simple regression models (not reported here) the correlations, although weak, are positive also in other cases, thus confirming $\mathrm{H} 1$ when international orientation and international capabilities are "in isolation", but the absence of these variables in multiple regression models means that other variables were better in explaining success.

For the theory development our findings may have triple implications: either the international orientation is not related to the success of INVs (and may be dropped from further research), or it should be measured differently, or else, more detailed analysis of relationships between these concepts is required: maybe these concepts are more important for "younger" INVs and their role diminishes with age of INVs?

The second hypothesis is confirmed except for two cases: small non-innovative companies evaluated their success in slightly (but significantly) more favorable terms than the non-innovative ones and the success through competition based on low prices may also be fragile (as small INVs are less predisposed to take advantage of economies of scale) However, other measures related to innovation and product development were positively correlated with both measures of success perception.

Supplying the goods of high quality is the best predictor of success perceptions, because this factor is the most often present in the composite models, for both small and medium-sized companies. 
The third hypothesis is "rather" not confirmed within Porter's framework. Only "strong" strategies, primarily strong differentiation, appear in the models. The stuck-in-themiddle situations do not arise systematically as the most disadvantageous ones (the correlation analysis showed negative impact of strategic clutter only for medium-sized firms). However, it should be stressed that Porter's theory-derived concepts have not been overshadowed by other variables in the composite models and could be explored in further research.

The fourth and fifth hypotheses are confirmed: taking into account industrial branches and two main export markets led to obtaining linear regression models with significant coefficients. Moreover, these two factors made it possible to integrate most of the outliers, removed in other models considered here.

Referring to the second objective of this paper, i.e. stability analysis, the most disparate results have been revealed for the small enterprises where only product development policy appeared to be positively correlated with a success declaration.

As far as medium-sized companies are concerned, two variables were positively correlated with the two success perception measures: competing with high quality and superiority over competitors in terms of product development and/or adaptation. Strategic disarray (Porter's stuck-in-the middle strategic situation) was negatively correlated with perception of success.

The factors which appear to be most positively linked to the perception of success across two groups of firms and two measures of the success perceptions are high-quality products, good product development strategy (superior to competitors) and capability to create unique, not easily substitutable products, i.e. differentiation capacity. Although a "window of success" linked to no-innovation strategy and low prices appeared in the case of small enterprises, it should be stressed that good quality and new product introduction were even more strongly correlated with the success perceptions.

In our opinion these findings lead to a conclusion that considering the SMEs as a uniform or homogeneous category by researchers and public policy-makers is a simplification and more efforts should be made to analyze differences within the SMEs.

Insignificant correlations between four measures of stuck-in the middle strategic clutters (instead of strong negative correlations) may indicate that the typology of competitive strategies is more complex than the one proposed by M. E. Porter. The research on "hybrid" strategies and "disruptions" (U-turns) in strategies could enrich this classification.

\section{Limitations and directions for future research}

The limitation of the study is that no "hard data" have been used related to the measurement of the INVs success. Although subjective measures of success are frequently used in the management research, maybe in the future, combining databases from business intelligence agencies with survey-based data will make it possible to overcome manager's unwillingness to disclose information about financial performance.

Another limitation is that the INVs success is analyzed for one year only. A few-year, panel-type research would give more viable information about relationships between strategic choices and the success on the market.

The success of non-innovative (as defined by Oslo manual) small enterprises leads to a conclusion that the concept of innovation should be reconsidered and expanded to capture the specificity of this phenomenon.

Finally, research comparing "true" born globals (operating worldwide also in distant markets) with international new ventures and with non-exporting enterprises, similarly to Choquette et al. (2017) study, should be also done in Poland. 


\section{References}

Androniceanu, A., \& Popescu, C.R. (2017). An inclusive model for an effective development of the renewable energies public sector. Administratie si Management Public, (28), 8196.

Baranowska-Prokop, E., \& Sikora, T. (2014). Relationship between competitive strategies and the success perception of Polish-born globals. International Journal of Management and Economics, 43, 94-113.

Baranowska-Prokop, E., \& Sikora, T. (2016). Postrzeganie innowacyjności oraz jej związku z sukcesem firmy przez kadrę menedżerską polskich przedsiębiorstw wcześnie umiędzynarodowionych. Marketing iRynek, 8, 25-31.

Baranowska-Prokop, E., \& Sikora, T. (2017). Innovativeness and success perception of Polish small- and medium-sized international new ventures. Journal of International Studies, 10, 134-146.

Choquette, E., Rask, M., Sala, D., \& Schröder, Ph. (2017). Born Globals -Is there fire behind the smoke? International Business Review, 26, 448-460.

Cieślik, A., \& Michałek, J. (2018). Process and product innovations, multi-product status and export performance: firm-level evidence from V-4 countries. Equilibrium. Quarterly Journal of Economics and Economic Policy, 13(2), 233-250. https://doi.org/10.24136/eq.2018.012.

Cieślik, J. (2010). Internacjonalizacja polskich przedsiębiorstw. Aktualne tendencje implikacje dla polityki gospodarczej. Nauka dla Praktyki i Polityki Gospodarczej, 1.

Contractor, F. J. (2007). Is international business good for companies? The evolutionary or multi-stage theory of internationalization vs. transaction costs perspective. Management International Review, 47, 453-475.

Coviello, N. E. (2006). The network dynamics of international new ventures. Journal of International Business Studies, 37, 713-731.

Crick, D. (2009). The internationalization of born global and international new venture SMEs. International Marketing Review, 26, 453-476.

Danik, L., \& Kowalik, I. (2013). The studies on born global companies - a review of research methods. Journal of Economics \& Management, 13, 9-26.

Danik, L., \& Kowalik, I. (2015). Success Factors and Development Barriers Perceived by the Polish Born Global Companies. Empirical Study Results. Journal of East European Management Studies, 20, 360-390.

Duliniec, E. (2011). Koncepcje przedsiębiorstw wcześnie umiędzynarodowionych. Rozważania terminologiczne. Gospodarka Narodowa, 1-2, 63-80.

Eisenhardt, K. M., \& Martin, J. A. (2000). Dynamic capabilities: what are they? Strategic Management Journal, 21, 1105-1121.

Ehrenberger, M., Koudelkova, P., \& Strielkowski, W. (2015). Factors influencing innovation in small and medium enterprises in the Czech Republic. Periodica Polytechnica Social and Management Sciences, 23(2), 73-83. https://doi.org/10.3311/PPso.7737

Evangelista, F. (2005). Qualitative insights into the international new venture creation process. Journal of International Entrepreneurship, 3, 179-198.

Fletcher, D. (2000). Learning to think global and act locally: experiences from the small business sector. Education+Training, 42, 211-219.

Gabrielsson, M., Kirpilani, V. H. M., Dimitratos, P., Solberg, C. A., \& Zucchella, A. (2008). Born globals: propositions to help advance the theory. International Business Review, 17, 385-401. 
Gomes, L., \& Ramaswamy, K. (1999). An empirical examination of the form of the relationship between multinationality and performance. Journal of International Business Studies, 30, 173-188.

Gorynia, M. (2007). Strategie zagranicznej ekspansji przedsiębiorstw. Warszawa: PWE.

Halldin, T. (2012). Born global firms - do they perform differently? CESIS Electronic Working Paper Series, Paper No. 269.

Idzikowski, W., \& Perechuda, I. (2018). Agile approach in a transforming organization, a descriptive study of chosen Polish companies with rapid revenue growth. Oeconomia Copernicana, 9(3), 461-475. https://doi.org/10.24136/oc.2018.023.

Jolly, V.K., Alahuhta, M., \& Jeannet, J. (1992). Challenging the incumbents: how high technology start-ups compete globally. Journal of Strategic Change, 1, 71-82.

Kamboj, Sh., \& Rahman, Z., (2015) Marketing capabilities and firm performance: literature review and future research agenda. International Journal of Productivity and Performance Management, 64, 1041-1067.

Knight, G., \& Cavusgil, S. T. (1996). The born global firm: a challenge to traditional internationalization theory. In S. T. Cavusgil, T. Madsen (Eds.), Advances in International Marketing, 8, Greenwich, 11-26.

Knight, G., \& Cavusgil, S. T. (2004). Innovation, organizational capabilities and born global firm. Journal of International Business Studies, 35, 15-35.

Kowalik, I., \& Baranowska-Prokop, E. (2013). Determinanty powstawania i motywy ekspansji polskich przedsiębiorstw wcześnie umiędzynarodowionych. GospodarkaNarodowa, 4, 41-64.

Madsen, T. K., \& Servais, P. (1997). The internationalization of born global firms - an evolutionary process. International Business Review, 6, 561-583.

Makadok, R. (2001). Toward a synthesis of the resource-based and dynamic-capability views of rent creation. Strategic Management Journal, 22, 387-401.

McDougall, P. P., Shane, S., \& Oviatt, B. M. (1994). Explaining the formation of international new ventures: the limits of theories from international business research. Journal of Business Venturing, 9, 469-487.

McDougall, P. P., \& Oviatt, B. M. (2000). International entrepreneurship: the intersection of two research paths. Academy of Management Journal, 43, 902-906.

McDougall, P. P., Oviatt, B. M., \& Shrader, R. C. (2003). A comparison of international and domestic new ventures. Journal of International Entrepreneurship, 1(1), 59-82.

Meyer, N., Meyer, D.F., \& Molefe, K.N. (2016). Barriers to small informal business development and entrepreneurship: The case of the Emfuleni region Polish Journal of Management Studies, 13 (1), 121-133.

Morgan, N. A., Vorhies, D. W., \& Mason, Ch. H., (2009). Market Orientation, Marketing Capabilities, and Firm Performance. Strategic Management Journal, 30 (8). 909-920.

Nowakowski, M. (1999). Wprowadzenie do zarządzania międzynarodowego. Warszawa: Difin.

Oviatt, B. M., \& McDougall, P. P. (1994). Toward a theory of international new ventures. Journal of International Business Studies, 25(1). 45-64.

Oviatt, B. M., \& McDougall P. (1995). Global start-ups: Entrepreneurs on a worldwide stage, The Academy of Management Executive, 9, (2), 30-43

Pietrasieński, P., \& Ślusarczyk, B. (2015). Internationalization of small and medium enterprises - Empirical research review on barriers to entry into foreign markets. Polish Journal of Management Studies, 11 (1), 113-123.

Porter, M. E. (1992). Strategia konkurencji. Metody analizy sektorów i konkurentów. Warszawa: PWE. 
Porter, M. E. (1998). Competitive strategy. Techniques for analyzing industries and competitors (with a new introduction). The Free Press.

Przybylska, K. (2010). Born Global - nowa generacja małych polskich przedsiębiorstw. Gospodarka Narodowa, 7-8, 63-83.

Przybylska, K. (2013). Born Global - nowa generacja małych przedsiębiorstw. Kraków: Uniwersytet Ekonomiczny w Krakowie.

Rasmussen, E. S., Madsen T. K., \& Evangelista, F. (2001). The founding of the born global company in Denmark and Australia: sensemaking and networking. Asia Pacific Journal of Marketing and Logistics, 13, 75-107.

Rennie, M. W. (1993). Global competitiveness: born global. McKinsey Quarterly, 4, 45-52.

Ruigrok, W., \& Wagner, H. (2003). Internationalization and performance: an organizational learning perspective. Management International Review, 43, 63-83.

Simionescu, M., \& Strielkowski, W. (2017). Brand loyalty and fashion marketing: A case study of Romanian youth. Marketing and Management of Innovations, 1, 25-31. doi:10.21272/mmi.2017.1-02

Servais, P., \& Rasmussen, E. S. (2000). Different types of international new ventures, Paper presented at the Annual Meeting of the Academy of International Business, Phoenix.

Spence, M. (2003). International strategy formation in small Canadian high-technology companies - A case study approach. Journal of International Entrepreneurship, 1, 277296.

Sullivan, D. (1994). measuring the degree of internationalization of a firm. Journal of International Business Studies, 25, 325-342.

Thomas, D. E., \& Eden, L. (2004). What is the shape of the multinationality-performance relationship? The Multinational Business Review, 12, 89-110. 